\title{
Antagonistic Variability among the Isolates of Trichoderma against Fusarium oxysporum f.sp. ciceri
}

\author{
Purnima Singh $^{1}$, Ashwini Kumar ${ }^{1 *}$, S. N. Singh ${ }^{1}$ and Sanjeev Kumar ${ }^{2}$ \\ ${ }^{I}$ Department of Plant Pathology, Jawaharlal Nehru Krishi Viswa Vidyalaya, Jabalpur, \\ Madhya Pradesh, India \\ ${ }^{2}$ Department of Plant Pathology, Dr. Rajendra Prasad Central Agriculture University Pusa, \\ Samastipur, Bihar, India
}

\section{A B S T R A C T}

\begin{tabular}{|c|}
\hline Keywords \\
\hline $\begin{array}{l}\text { Trichoderma, } \\
\text { Fusarium oxysporum } \\
\text { f. sp., ciceri, Chickpea } \\
\text { wilt }\end{array}$ \\
\hline Article Info \\
\hline $\begin{array}{l}\text { Accepted: } \\
28 \text { July } 2018 \\
\text { Available Online: } \\
10 \text { August } 2018\end{array}$ \\
\hline
\end{tabular}

Keywords

Trichoderma,

Fusarium oxysporum

f. sp., ciceri, Chickpea

Article Info

Accepted:

Available Online:

10 August 2018
Trichoderma has attained importance as a substitute of chemical pesticides all over the world. Hence, an attempt was intended to corroborate the positive relatedness of antagonistic ability. Among different isolates of Trichoderma isolated from rhizospheric soils has brought attention due to its highly antagonistic activity. The study aimed to determine the potency of native Trichoderma isolates against Fusarium oxysporum f.sp. ciceri under in vitro condition. Maximum per cent inhibition was recorded in isolate $\mathrm{T}_{3}$, followed by $\mathrm{T}_{15}, \mathrm{~T}_{7}$ and $\mathrm{T}_{5}$ in dual culture. All native rhizospheric isolates of Trichoderma were found significant in reducing mycelial growth of Fusarium oxysporum f.sp. ciceri. The significane of antagonistic potential of twenty Trichoderma isolates was scored on scale (1-5) for degree of antagonism against Fusarium oxysporum f.sp. ciceri. The result revealed that the highest antagonism was found in isolate $T_{3}$ ( $T$. harzianum) against chickpea wilt.

\section{Introduction}

Chickpea (Cicer arietimum L.) is one of the most important pulse crop grown in semi and tropical climate. In India, chickpea is ranked first in terms of production and consumption in the world. About $65 \%$ of global area with $68 \%$ of global production of chickpea is contributed by India (Amarender and Devraj, 2010). It covers an area of 82.18 Lakh ha with a production of 77.02 Lakh tons and productivity of $937 \mathrm{~kg}$ per ha. It occupies an area of 28.84 Lakh ha with the production of 30.12 Lakh tons, productivity being $1044 \mathrm{~kg}$ per ha in Madhya Pradesh (DPD, 2016-17).
Low yield of chickpea is attributed to its susceptibility to several fungal, bacterial and viral diseases. Fusarium wilt caused by Fusarium oxysporum Schlechtend Fr. f. sp. ciceri (Padwick) Matuo \& K. Sato, is the most important soil borne disease of chickpea throughout the world and particularly in the Indian Subcontinent, the Mediterranean Basin and California (Nene et al., 1987).

At the national level, chickpea yield losses encounter due to wilt may vary between five to ten percent (Dubey et al., 2007). Since the pathogen is both seed and soil borne, drenching with fungicides is very expensive 
and impractical. Therefore, integrated disease management strategies are the only solution to maintain plant health. These strategies should include minimum use of chemicals for checking the pathogen pollution, encouragement of beneficial biological agents to reduce pathogen inoculum, modification of cultural practices and use of resistant varieties (Bendre et al., 1998).

Among fungi, the most widely used biofungicides are Trichoderma sp. (Mukherjee et al., 2013). India alone is having more than 250 commercial formulations which are being used against many crops for sustainable agriculture (Mukherjee et al., 2013, Singh et al., 2012). Major mechanisms which are responsible for biocontrol potential of Trichoderma sp. are mycoparasitism, antibiosis, competition through rhizosphere competence and production of cell wall degrading enzymes. Trichoderma $s p$. is found in all climates over different geographically regions. Even though most Trichoderma $s p$. found on wild mushrooms and trees; soil or rhizospheric soil has been viewed as its main habitat (Mukherjee et al., 2013, Druzhinina et al., 2011). The study was conducted to find out the most effective isolates of Trichoderma against chickpea wilt pathogen Fusarium oxysporum f. sp. ciceri.

\section{Materials and Methods}

Collection, Isolation, Purification and identification of Pathogen and Trichoderma

F. oxysporum f. sp. ciceri was isolated from the infected roots of chickpea plants collected at Fusarium infested chickpea field in the Department of Plant Pathology, JNKVV, Jabalpur, M.P. India. Samples were brought in the laboratory of Plant Pathology for examination and isolation. For isolation of Trichoderma, soil samples were collected from rhizosphere of different plants (Table 1).
The infected root portion of chickpea variety JG-62 was used for isolation of $F$. oxysporum. $f . s p$. ciceri. The isolation was made by following standard tissue isolation procedure. The infected specimens were cut into small bits with help of scalpel and washed in running water. These bits were surface sterilized with 1 per cent of sodium hypochlorite solution for one minute then aseptically transferred to Petri plates containing the sterilized PDA medium and incubated at $25 \pm 2^{\circ} \mathrm{C}$.

For isolation of Trichoderma soil sample of 10 gm weight was weighed and placed in a beaker containing $45 \mathrm{ml}$ of sterile distilled water. After shaking thoroughly, it was allowed to stand for a few minutes. From the suspension, $1.0 \mathrm{ml}$ was taken out by using glass pipette and added to $9.0 \mathrm{ml}$ distilled water in a test tube and shaken well, this gives $10^{-4}$ dilution. One $\mathrm{ml}$ from $10^{-4}$ dilution is drawn and spread over the PDA plate. These plates were incubated in B.O.D incubator at $25 \pm 2{ }^{\circ} \mathrm{C}$. The plates were monitored regularly for the development of colonies. After three days of incubation, colonies were picked from periphery of the plates and transferred aseptically to another PDA plate.

The test pathogen and Trichoderma were purified by hyphal tip method. To obtain the sparse growth, the test pathogen and antagonist were inoculated on sterilized water agar in Petriplates from the original culture Petriplates. After two days the growth of the fungus was carefully examined under low power (10X) of microscope from the reverse side of Petriplates.

A single hyphal strand was located and its location was marked with a marker on bottom of Petriplates. Agar disc corresponding to the marked area was cut with a sterilized cork borer and transferred aseptically on to PDA in Petriplates and incubated at $25 \pm 2{ }^{\circ} \mathrm{C}$. 
The cultures were identified on the basis of the descriptions given in the monograph on the genus Fusarium (Booth, 1971). F. oxysporum. f.sp. ciceri showed circular, raised, cottony creamy white colony with entire margins. The microconidia was oval to cylindrical, straight or curved and measure $2.5-3.5 \times 5-11 \mathrm{~mm}$.

The green colour colonies of Trichoderma were identified on the basis of branching of conidiophores, shape of phialides, emergence of phialides and spore characters (Gams and Bisset, 1998).

\section{Antagonistic Variability}

The antagonistic variability in twenty isolates of Trichoderma was studied by Dual culture method (Morton and Stroube, 1955).

A mycelial disc $(2 \mathrm{~mm})$ was cut aseptically from the margins of actively grown region of five day old cultures of Trichoderma isolates and inoculated at one end of petriplate $(1 \mathrm{~cm}$ away from edge of petriplate) with sterilized PDA medium and simultaneously, $2 \mathrm{~mm}$ disc of test pathogen at opposite end.

For each treatment three replicates were maintained and were incubated at $25 \pm 2^{\circ} \mathrm{C}$. Plate was kept without antagonist to serve as control. Observations were recorded for linear growth of $F$. oxysporum. f.sp. ciceri and per cent inhibition by antagonist.

Per cent inhibition of the pathogen over control was measured by using following formula.

$\mathrm{I}(\%)=(\mathrm{C}-\mathrm{T}) / \mathrm{C} \times 100$

Where,

$\mathrm{I}=$ Percent growth inhibition

$\mathrm{C}=$ Growth in control.

$\mathrm{T}=$ Growth in Dual culture.

\section{Results and Discussion}

Data presented in the Table 2 (Plate 1) clearly indicated that, the linear growth of pathogen in presence of antagonist varied from $10.26 \mathrm{~mm}$ to $25.33 \mathrm{~mm}$ as compared to control $(75.50$ $\mathrm{mm})$. The minimum linear growth of $F$. oxysporum f.sp. ciceri was recorded with $\mathrm{T}_{3}$ $(10.26 \mathrm{~mm})$ isolate, followed by $\mathrm{T}_{15}(11.63$ $\mathrm{mm})$ and $\mathrm{T}_{7}(12.5 \mathrm{~mm})$. Whereas, maximum linear growth of $F$. oxysporum f.sp.ciceri of $25.33 \mathrm{~mm}$ recorded with $\mathrm{T}_{11}$ isolate, followed by $24.00 \mathrm{~mm}$ and $23.00 \mathrm{~mm}$ in $\mathrm{T}_{10}$ and $\mathrm{T}_{4}$ isolates respectively. Mycelial growth of Fusarium. oxysporum f.sp cicer was significantly inhibited by all the isolates of Trichoderma. The per cent inhibition ranged from $66.43 \%$ to $86.4 \%$. Maximum inhibition per cent $(86.4 \%)$ was recorded with isolates $\mathrm{T}_{3}$. The minimum inhibition per cent was recorded in $\mathrm{T}_{11}(66.43 \%)$ which was at par with $\mathrm{T}_{4}(69.53 \%), \mathrm{T}_{10}(68.21 \%)$ and $\mathrm{T}_{11}$ (66.43\%). Further, all twenty Trichoderma isolates were grouped into five classes most efficient, efficient, moderately efficient, poor and very poor based on the overgrowth of Trichoderma on the pathogen, as described by Bell et al., (1982) (Table 3). Out of twenty Trichoderma isolate $\mathrm{T}_{3}$ was found highly effective and exhibited maximum inhibition per cent against Fusarium oxysporum f.sp. ciceri. 14 isolates fell into antagonism class '2', four Trichoderma isolates into class ' 3 ' and only 1 isolate into class ' 4 '.

The potential of Trichoderma sp. had been recognized as biocontrol agent against soil borne pathogen by Weindling (1932), Upadhyay and Mukhoupadhaya (1986), Jha and Jalali (2006) and Singh et al., (2007). Variations in antagonism among different isolates of Trichoderma were found significant against $F$. oxysporum. f.sp. ciceri. Maximum percent inhibition was found in T3 isolate followed by $\mathrm{T} 15, \mathrm{~T} 5, \mathrm{~T} 7$ and $\mathrm{T} 8$ as compared to other isolate (Table 2). 
Table.1 List of Trichoderma isolates collected from different locations of Jabalpur

\begin{tabular}{|c|c|c|c|}
\hline S. No. & Isolate code & Crop & Location \\
\hline $\mathbf{1}$ & $\mathrm{T}_{1}$ & Red gram & Forestry field \\
\hline $\mathbf{2}$ & $\mathrm{T}_{2}$ & Green gram & Talab area \\
\hline $\mathbf{3}$ & $\mathrm{T}_{3}$ & Soybean & Dusty area \\
\hline $\mathbf{4}$ & $\mathrm{T}_{4}$ & Soybean & IFS, college campus \\
\hline $\mathbf{5}$ & $\mathrm{T}_{5}$ & Maize & Adhartal \\
\hline $\mathbf{6}$ & $\mathrm{T}_{6}$ & Soybean & Farmer's field \\
\hline $\mathbf{7}$ & $\mathrm{T}_{7}$ & Rice & Marmer's field \\
\hline $\mathbf{8}$ & $\mathrm{T}_{8}$ & Chilli & Iemalia \\
\hline $\mathbf{9}$ & $\mathrm{T}_{9}$ & Mango & Soil science field \\
\hline $\mathbf{1 0}$ & $\mathrm{T}_{10}$ & Rice & BSP, field \\
\hline $\mathbf{1 1}$ & $\mathrm{T}_{11}$ & Rice & Maharajpur \\
\hline 12 & $\mathrm{~T}_{12}$ & Neem & Iemalia \\
\hline 13 & $\mathrm{~T}_{13}$ & Banana & IFS \\
\hline 14 & $\mathrm{~T}_{14}$ & Rice & College campus \\
\hline 15 & $\mathrm{~T}_{15}$ & Betel vine & Sehora \\
\hline 16 & $\mathrm{~T}_{16}$ & Soybean & BSP,field \\
\hline 17 & $\mathrm{~T}_{17}$ & Okra & BSP,field \\
\hline 18 & $\mathrm{~T}_{18}$ & Soybean & Horticulture field \\
\hline 19 & $\mathrm{~T}_{19}$ & Okra & Iemalia \\
\hline $\mathbf{2 0}$ & $\mathrm{T}_{20}$ & Citrus & \\
\hline & & & \\
\hline
\end{tabular}

Table.2 Average linear growth and percent inhibition in growth of Fusarium oxysporum f.sp ciceri by isolates of Trichoderma after five days of incubation period

\begin{tabular}{|c|c|c|}
\hline Isolate Code & Linear growth $(\mathbf{m m})$ of $\boldsymbol{F}$. oxysporum f.sp. ciceri & Per cent inhibition \\
\hline $\mathrm{T}_{1}$ & 15.00 & 80.13 \\
\hline $\mathrm{T}_{2}$ & 18.66 & 75.27 \\
\hline $\mathrm{T}_{3}$ & 10.26 & 86.40 \\
\hline $\mathrm{T}_{4}$ & 23.00 & 69.53 \\
\hline $\mathrm{T}_{5}$ & 12.33 & 83.66 \\
\hline $\mathrm{T}_{6}$ & 15.00 & 80.13 \\
\hline $\mathrm{T}_{7}$ & 12.5 & 83.44 \\
\hline $\mathrm{T}_{8}$ & 13.10 & 82.64 \\
\hline $\mathrm{T}_{9}$ & 19.00 & 74.83 \\
\hline $\mathrm{T}_{10}$ & 24.00 & 68.21 \\
\hline $\mathrm{T}_{11}$ & 25.33 & 66.43 \\
\hline $\mathrm{T}_{12}$ & 15.76 & 79.11 \\
\hline $\mathrm{T}_{13}$ & 20.00 & 73.53 \\
\hline $\mathrm{T}_{14}$ & 13.33 & 82.33 \\
\hline $\mathrm{T}_{15}$ & 11.63 & 84.59 \\
\hline $\mathrm{T}_{16}$ & 16.66 & 77.92 \\
\hline $\mathrm{T}_{17}$ & 17.50 & 76.82 \\
\hline $\mathrm{T}_{18}$ & 14.66 & 80.57 \\
\hline $\mathrm{T}_{19}$ & 13.66 & 81.90 \\
\hline $\mathrm{T}_{20}$ & 13.16 & 82.55 \\
\hline $\mathrm{Control}^{\mathrm{SE}(\mathrm{m}) \pm}$ & 75.50 & 0 \\
\hline $\mathrm{CD}$ & 0.81 & 1.06 \\
\hline
\end{tabular}

*Average of three replications 
Table.3 Classification of Trichoderma isolates antagonistic against Fusarium oxysporum f.sp ciceri based on Bell et al., (1982)

\begin{tabular}{|c|}
\hline Antagonism class \\
\hline 1 \\
\hline 2 \\
\hline 3 \\
\hline 4 \\
\hline 5
\end{tabular}

\begin{tabular}{|l|c|}
\multicolumn{1}{c|}{ Isolates } & No. of isolates \\
\hline $\mathrm{T}_{3}$ & 1 \\
\hline $\mathrm{T}_{1}, \mathrm{~T}_{2}, \mathrm{~T}_{4}, \mathrm{~T}_{5}, \mathrm{~T}_{6}, \mathrm{~T}_{7}, \mathrm{~T}_{8}, \mathrm{~T}_{10}, \mathrm{~T}_{14}, \mathrm{~T}_{15}, \mathrm{~T}_{16}, \mathrm{~T}_{18}, \mathrm{~T}_{19}, \mathrm{~T}_{20}$ & 14 \\
\hline $\mathrm{T}_{9}, \mathrm{~T}_{11}, \mathrm{~T}_{13}, \mathrm{~T}_{17}$ & 4 \\
\hline $\mathrm{T}_{12}$ & 1 \\
\hline Nil & Nil \\
\hline
\end{tabular}

\begin{tabular}{|c|}
\hline Antagonism class \\
\hline 1 \\
\hline 2 \\
\hline 3 \\
\hline 4 \\
\hline 5
\end{tabular}

Isolates

Trichoderma overlapped the colony of fusarium and whole surface of media

Trichoderma grew and it covered $2 / 3$ of the surface of the media

Trichoderma and Fusarium colonized each one half of the surface of the media

Fusarium grew and it covered $2 / 3$ of the surface of the media

Fusarium grew and covered entire surface of media
Remark

Most efficient

Efficient

Moderately efficient

Poor

Very poor
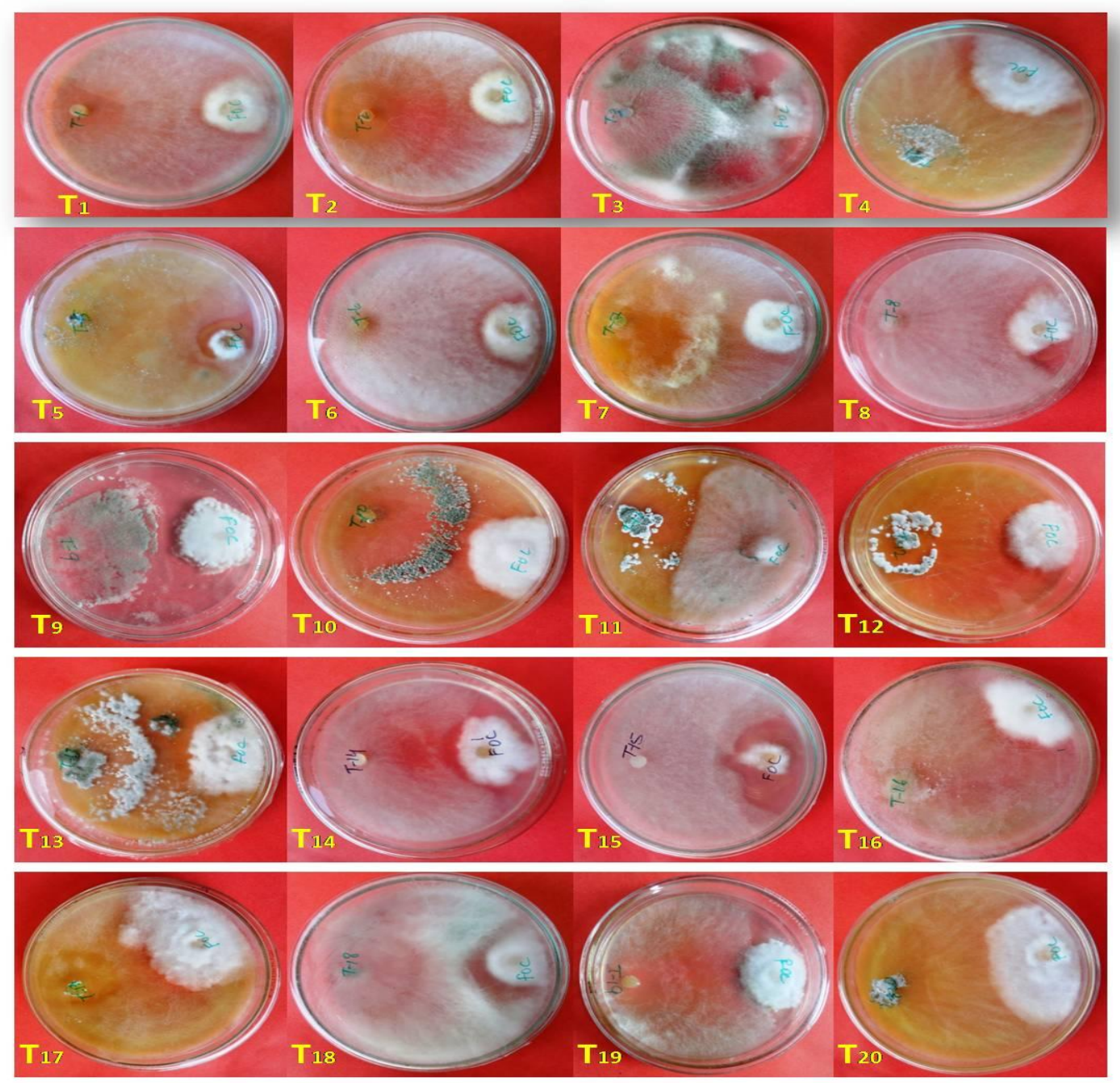

Plate 1: Inhibition of Fusarium oxysporum f.sp. ciceri by isolate of Trichoderma (T-1 to $T-20$ ) in vitro by dual culture method 
Out of twenty isolates T3 exhibited highest per cent inhibition $(86.40 \%)$. As all the isolates of Trichoderma were found medium to fast growing, it may be due to the maximum reduction in linear growth of $F$. oxysporum f.sp. ciceri attributed due to faster growth of interacting isolates of Trichoderma rather than its direct influence. Similar observations had also been reported by Patibanda and Sen (2004) while studying Aspergillus niger vs $F$. oxysporum. f.sp. melonis. The variability among different isolates of Trichoderma isolates might be due to variation in mycelium coiling rate, sporulation and fungitoxic metabolites (Barkat et al., 2006 and Jegathambigas, 2010). The degree of antagonism (Table 3) between each Trichoderma isolate and pathogen in dual culture was scored on scale 1-5 as proposed by Bell et al., (1982). In present study highest antagonism was observed in isolate T3 ( $T$. harzianum). However, differences between isolates T5, T7 and T15 with $83.66,83.44 \%$ and $84.59 \%$ respectively with T3 $(86.4 \%)$ were found statistically at par against $F$. oxysporum. f.sp. ciceri. Singh et al., (2013) have also reported the similar findings antagonistic variability among the isolates using dual culture and reported significant reduction in radial growth F. oxysporum. f.sp. ciceri.

\section{Acknowledgement}

Authors are thankful to Professor and Head, Department of Plant Pathology for providing facilities for conducting the present research work.

\section{References}

Amarender R, Devraj M (2010). Growth and instability in chickpea production in India. www.krisat.org Accessed on 15 February 2011
Barakat R.M., Al- Mahareeq F. and Al-Masri M.I. 2006. Biological control of Sclerotium rolfsii by usin indigenous Trichoderma sp. Isolates from Palestine. Hebron Universiy Research Journal 2: 27-47.

Bell D.K., Wells H. D. and Markham, C.R. 1982, In vitro antagonism of Trichoderma spp. against six fungal plant pathogens. Phytopathology 72:379-382.

Bendre, N. J. and Barhate, B. G. (1998) A Souvenir on disease management in chickpea. M.P.K.V. Rahuri during 10th Dec. 1998.

Booth C. (1971). The Genus Fusarium. Commonwealth Mycology Institute, Eastern Press Limited, Kew Surrey. Pp. 237.

DPD, Bhopal. 2015-16. Report of the national level monitoring team, http://dpd.dacnet.nic.in

Druzhinina I. S., Seidl-Seiboth V., HerreraEstrella A., Horwitz B. A., Kenerley C. M., Monte E., Mukherjee P. K., Zeilinger S., Grigoriev I. V., Kubicek C. P. (2011), Trichoderma: the genomics of opportunistic success. Nat Rev Microbiol 9:749-759

Dubey, S. S., Suresh, M. and Singh, B. (2007) Evaluation of Trichoderma species against Fusarium oxysporum $f$. sp. Ciceri for integrated management of chickpea wilt. Biol. Control, 40(1):118127.

Gams W. and Bissett J. 1998. Morphology and Identification of Trichoderma. In Trichoderma and Gliocladium. genus. Myco.Res. 100: 923-935.

Jegathambigai V., Wilson R.S. and Wijesundera R.L.C. 2010. Effect of Trichoderma sp. On S. Rolfsii, the causative agent of collar rot of on Zamioculcas zamiifolia and an on farm method to mass produce Trichoderma species. Plant pathology Journal 1: 1-9. 
Jha P.K. and Jalali B.L. 2006. Biocontrol of pea rot incited by Fusarium solani f.sp. pisi with rhizospheremycoflora. Indian Phytopatholgy. 59: 41-43.

Mortan D.T. and Stroube W.H. 1955. Antagonistic and stimulatory effects of microorganism upon Sclerotium rolfsii. Phytopathology, 45:419-420

Mukherjee K., Sampath A. K., Kranthi S., Mukherjee P. K. (2013) Biocontrol potential of three novel Trichoderma strains: isolation, evaluation and formulation A, 3 Biotech DOI 10.1007/s13205-013-0150-4.

Nene, Y. L. and Reddy, M. V. (1987) Chickpea Diseases and their Control. In: Saxena, M. C. and Singh K. B., The Chickpea. Oxon, UK: CAB International. pp. 233-270.

Padwick, G. W. (1939) Report of the Imperial Mycologist. Scientist Reports, Agricul. Res. Inst. New Dehli. (40): 94-101 (1941).

Patibanda A.K. and Sen B. 2004. In vitro screening of Aspergillus niger van Teigh against Fusarium oxysporum f.sp. melonis, muskmelon wilt pathogen.
Journal of Biological Control 18(1): 2934.

Singh A., Mohammad Shahid, Srivastva M. and Biswas S.K. 2013. Molecular and Antagonistic Variability of Trichoderma atroviride against Legume crop Pathogens in Uttar Pradesh, India. International Journal of Bioresouce and Stress Management, 4(4):582-587

Singh H. B., Singh B. N., Singh S. P., and Sharma B. K. (2012). Exploring different avenues of Trichoderma as a potent bio-fungicidal and plant growth promoting candidate- an overview, Rev Plant Pathol, 5, pp.315-426.

Singh U.S. and Joshi B.B. 2007. Mass multiplication of Trichoderma harzianum on on sugarcane press mud. Indian Phytopathology 60:530-531.

Upadhyay J.P. and Mukhopadhyay A.N. 1986. Biological control of Sclerotium rolfsii by Trichoderma harzianum in sugarbeet. Tropical Pest Management. 32: 215-220.

Weindling R. 1932. Trichoderma lignorum as a parasite of other soil fungi. Phytopathology 22: 837-845.

\section{How to cite this article:}

Purnima Singh, Ashwini Kumar, S. N. Singh and Sanjeev Kumar. 2018. Antagonistic Variability among the Isolates of Trichoderma against Fusarium oxysporum f.sp. ciceri. Int.J.Curr.Microbiol.App.Sci. 7(08): 4833-4839. doi: https://doi.org/10.20546/ijcmas.2018.708.509 